\title{
KAJIAN TENTANG IMPLEMENTASI MODUL BAHAN KIMIA DI RUMAH TANGGA PADA SISWA KELAS VII DI SMP NEGERI 2 SIDOARJO TAHUN PELAJARAN 2005/2006
}

\author{
Herowati \\ Prodi Pendidikan IPA, Universitas Wiraraja Sumenep
}

\begin{abstract}
ABSTRAK
Penelitian ini bertujuan untuk menjawab pertanyaan umum: "Apakah modul bahan kimia di rumah tangga yang telah dikembangkan oleh Susilawati (2004) efektif untuk digunakan dalam pembelajaran di SMP?", dan menjawab pertanyaan yang lebih operasional: (1) Bagaimanakah kualitas proses pembelajaran dengan menggunakan modul bahan kimia di rumah tangga yang telah dikembangkan?; (2) Bagaimanakah ketuntasan belajar siswa SMP kelas VII dalam mempelajari pokok bahasan bahan kimia di rumah tangga menggunakan modul bahan kimia di rumah tangga yang telah dikembangkan?; (3) Bagaimana persepsi siswa terhadap modul bahan kimia di rumah tangga? Data penelitian berupa data kuantitatif skor tes untuk materi bahan kima di rumah tangga, serta data kuantitatif lembar observasi ranah psikomotorik, dan data kuantitatif berupa skor siswa hasil pengolahan angket yang diinterpretasikan berdasarkan kriteria yang dinyatakan oleh Arikunto, dan data kualitatif hasil pengolahan lembar observasi diskusi dinyatakan dengan persentase. Hasil penelitian yang diperoleh adalah: Secara umum modul bahan kimia di rumah tangga yang dikembangkan oleh Susilawati (2004) adalah efektif untuk diimplentasikan dalam pembelajaran di SMP. Secara operasional diperoleh bahwa: (1) kualitas proses pembelajaran ditinjau dari: (a) aspek afektif yaitu keaktifan siswa pada saat diskusi dengan kategori paling aktif dalam kegiatan menjawab pertanyaan; (b) aspek psikomotorik siswa pada saat praktikum tergolong dalam kategori sangat aktif; (2) ketuntasan belajar siswa dalam mempelajari materi bahan kimia di rumah tangga sebesar 90,0\% dengan skor rata-rata kelas sebesar 76,10. Hal ini menunjukkan bahwa hasil belajar telah memenuhi kriteria standar ketuntasan belajar mengajar (SKBM); (3) data persepsi siswa terhadap pembelajaran dengan menggunakan modul diperoleh 55,0\% (22 orang) menyatakan sangat setuju dan 18 orang siswa $(45,0 \%)$ menyatakan setuju. Hal ini menunjukkan bahwa siswa menyetujui pelaksanaan pembelajaran dengan menggunakan modul bahan kimia di rumah tangga model learning cycle (LC). Dengan demikian hasil penelitian ini dapat dijadikan bahan pertimbangan dalam memilih strategi belajar 'baru' untuk mengaktualisasikan keterampilan proses sains secara maksimal dalam pembelajaran dan dapat dijadikan sebagai acuan dalam pengembangan modul untuk materi yang lain.
\end{abstract}

Kata Kunci: Modul, Pembelajaran, Bahan Kimia di Rumah Tangga, Model Learning Cycle (LC)

\section{PENDAHULUAN}

Dari beberapa model pembelajaran berlandaskan konstruktivistik learning cycle (LC) dipromosikan sebagai salah satu alternatif strategi belajar yang baru. Learning cycle (LC) merupakan model pembelajaran konstruktivis generasi pertama yang digunakan dan dikembangkan pada suatu program Ilmu Pengetahuan Alam (IPA) oleh Profesor Robert Karplus pada tahun 1974 yang didasarkan pada teori belajar Piaget. Model ini merupakan salah satu model pembelajaran konstruktivis yang dapat diimplementasikan baik sebagai instruktional stategy maupun dalam bahan ajar. Implementasi learning cycle (LC) dalam bahan ajar mempunyai fase-fase belajar yang pada awalnya memiliki tiga fase. Implementasi learning cycle (LC) dalam bahan ajar untuk pengajaran kimia yang telah dilakukan dengan menggunakan model pemaparan materi mengikuti fasefase dalam learning cycle 3 fase sebagai satu kesatuan siklus yaitu fase eksplorasi, fase pengenalan konsep, dan fase aplikasi konsep. Pada akhir proses pembelajaran dilakukan refleksi terhadap kegiatan pembelajaran. Fase eksplorasi bertujuan untuk mengajak siswa memikirkan konsepkonsep yang berkaitan dengan materi yang diajarkan melalui keterbatasan atau tindakan siswa yang mengeksplorasi objek, peristiwa atau situasi menarik yang dapat diamati dan juga agar siswa dapat menerapkan pengetahuan awal siswa serta untuk meningkatkan rasa ingin tahu siswa terhadap materi baru. Fase pengenalan konsep bertujuan untuk menjelaskan konsep 
yang telah ditemukan siswa, menyamakan persepsi antara konsep yang telah disepakati dengan konsep yang telah dibangun pada kegiatan eksplorasi. Fase aplikasi konsep bertujuan untuk menerapkan konsep yang sudah dipelajari pada situasi baru serta memahami hubungan antara konsep yang dipelajari dengan konsep-konsep yang lain. Pada akhir kegiatan pembelajaran dilakukan refleksi yang bertujuan untuk mengajak siswa memikirkan konsep yang baru dipelajari atau berpikir kebelakang tentang pengetahuan yang dibentuk selama proses pembelajaran.

Adanya fase-fase ini dapat memberikan lingkungan belajar yang konstruktivis dan memperbaiki mutu proses pembelajaran. Salah satu bentuk bahan ajar yang dapat dipelajari oleh siswa secara mandiri dan dapat digunakan sebagai sumber belajar adalah modul.

Hasil penelitian Susilawati (2004) menghasilkan modul bahan kimia di rumah tangga. Pada modul pembelajaran tersebut terdiri atas 2 bagian yaitu bagian pendahuluan dan bagian isi. Bagian pendahuluan terdiri atas beberapa komponen yakni: halaman, kata pengantar, daftar isi, daftar tabel, daftar gambar, panduan penggunaan modul. Pada bagian isi terdiri atas 4 kegiatan belajar. Kegiatan belajar ini membahas semua sub konsep yang harus dipelajari.

Uraian kegiatan belajar terdiri atas beberapa komponen yang meliputi: rumusan kompetensi dasar, indikator hasil belajar, tahap-tahap pembelajaran modul model learning cycle tiga fase yang di dalamnya terdapat pertanyaan-pertanyaan bimbingan, lembar kerja siswa, uraian materi, informasi dan tugas. Uraian tersebut juga dilengkapi dengan rangkuman, soal evaluasi, panduan jawaban evaluasi, umpan balik dan daftar pustaka.

Modul tersebut belum divalidasi empirik sehingga belum dapat diketahui efektivitas dan efisiensinya. Oleh sebab itu perlu dilakukan peneltian tentang implementasi modul learning cycle (LC) bahan kimia di rumah tangga.
Penelitian tentang kajian penerapan modul learning cycle (LC) pada siswa SMA telah banyak dilakukan diantaranya oleh Rohmawati (2003), Fitriyah (2003), Ekowati (2003), Marhedrasari (2003), Sa'diyah (2003), Khusniyah (2003). Penerapan modul learning cycle (LC) memberikan hasil yang positif terhadap hasil belajar siswa, terhadap keaktifan siswa dalam belajar, dan sikap yang positif terhadap modul yang digunakan sebagai bahan ajar dalam proses pembelajaran.

Penelitian implementasi modul learning cycle (LC) di SMP belum dilakukan walau telah dikembangkan beberapa modul untuk beberapa pokok bahasan diantaranya seperti ciri-ciri reaksi kimia (Sriningsih,2004), zat adiktif dan psikotropika (Setiawati,2005), unsur, senyawa dan campuran (Ulfah,2005).Dalam penelitian ini penulis melakukan penelitian kajian tentang implementasi modul pada pokok bahasan bahan kimia di rumah tangga yang telah dikembangkan oleh Susilawati (2004) pada siswa SMP kelas VII.

Modul yang dikembangkan hanya sampai pada tingkat validasi oleh dua dosen jurusan kimia Universitas Negeri Malang (UM) dan lima guru kimia SMP di Malang dengan tingkat validasi sebesar $86,9 \%$ yang berarti valid (tidak perlu revisi). Untuk mengetahui kelayakan modul bahan kimia di rumah tangga tersebut sebagai media pembelajaran, maka diperlukan implementasi modul pada siswa di sekolah untuk mengetahui kualitas proses pembelajaran, ketuntasan belajar dan persepsi siswa terhadap modul model learning cycle. Dari uraian diatas, maka dalam penelitian ini mengambil judul: "Kajian Tentang Implementasi Modul Bahan Kimia di Rumah Tangga Pada Siswa Kelas VII Di SMP Negeri 2 Sidoarjo Tahun Pelajaran 2005/2006".

\section{METODE PENELITIAN}

Penelitian ini dilakukan dengan menggunakan pendekatan penelitian deskriptif yang artinya bahwa peneliti 
berusaha memperoleh informasi dari keadaan yang sedang berlangsung. Penelitian ini ditempuh untuk mengetahui kualitas proses pembelajaran dengan modul, ketuntasan belajar siswa setelah belajar dengan modul, dan persepsi siswa terhadap modul itu sendiri. Rancangan penelitian yang digunakan adalah rancangan pra eksperimental. Penelitian ini dilaksanakan pada kelas VII-7 semester 1 tahun ajaran 2005/2006 pada akhir bulan September sampai dengan bulan oktober 2005 di SMP Negeri 2 Sidoarjo.

\section{HASIL DAN PEMBAHASAN}

Model pembelajaran dengan menggunakan modul menuntut siswa untuk belajar secara mandiri. Berdasarkan skenario pembelajaran yang telah ada, pelaksanaan belajar mandiri adalah dengan membiarkan siswa belajar sendiri maupun berkelompok mengikuti tahapan-tahapan atau fase-fase dalam modul. Dari sini siswa akan mengkonstruksi pengetahuannya sendiri dengan cara mengaitkan konsepkonsep yang ada dalam modul dengan konsep-konsep yang ada dalam struktur kognitifnya. Dengan menggunakan metode diskusi diharapkan proses mengkonstruksi pengetahuan dapat dilakukan dengan mudah oleh siswa.

\subsection{Proses Pembelajaran dengan Modul Bahan Kimia di Rumah Tangga}

Pada proses pembelajaran dengan menggunakan modul bahan kimia di rumah tangga ini mengikuti tahapan fase leaning cycle (LC) 3 fase. Kegiatan pembelajaran diawali dengan fase explorasi (exploration) siswa belajar melalui keterlibatan atau tindakan mereka dengan mengekplorasi objek, peristiwa atau situasi menarik yang dapat diamati. Pada fase ini diawali dengan kegiatan demonstrasi oleh guru untuk menarik minat dan perhatian siswa dan memberikan pertanyaan-pertanyaan yang bertujuan untuk mengakses pengetahuan awal yang dimiliki siswa tentang konsep dasar materi yang akan disampaikan. Pengetahuan awal siswa belum tentu benar, bisa juga terdapat kesalahan konsep, jadi pada fase ini guru dapat mendeteksi ada tidaknya kesalahan konsep sejak awal. Hal ini juga dimaksudkan agar siswa terbiasa berfikir dari tingkat yang sederhana ke tingkat yang kompleks.

Pada fase eksplorasi siswa cukup antusias dalam memperhatikan demonstrasi, hal ini disebabkan dalam diri siswa sudah timbul sikap menerima terhadap pembelajaran dan merupakan pemanasan untuk berfikir kreatif. Siswa sudah mulai terbiasa menyadari adanya masalah dari demonstrasi yang telah dilakukan. Siswa tidak hanya menjadi pengamat yang pasif. Pada fase eksplorasi siswa dapat menggali pengetahuan dari percobaan yang ada pada lembar kegiatan siswa dalam modul. Dari kegiatan percobaan ini siswa berusaha menemukan jawaban atas pertanyaan yang mereka miliki lalu menganalisis data hasil percobaan untuk mendapatkan suatu pengetahuan baru atau memantapkan pengetahuan yang telah dimilikinya. Peran guru disini hanya sebagai pendamping yang memfasilitasi dan mengarahkan siswa untuk merumuskan konsep. Data tentang perkembangan keaktifan siswa pada saat praktikum disajikan selengkapnya pada Tabel 4.2 (dapat dilihat pada lampiran 2). Dari data tentang perkembangan keaktifan siswa pada saat praktikum dapat disimpulkan bahwa pada kegiatan praktikum sangat disukai oleh siswa. Siswa sangat antusias dalam melakukan percobaan, hal ini disebakan karena siswa diberi kebebasan dalam melakukan percobaan dengan cara mereka sendiri yang dilakukan secara berkelompok sehingga terjadi cooperative learning. Selain itu, kegiatan pembelajaran yang mengajak siswa untuk terjun langsung ke lapangan membuat keaktifan siswa meningkat. Hal ini terlihat pada jumlah siswa yang aktif pada kegiatan pembelajaran di pertemuan kelima mencapai lebih dari $50,0 \%$ atau tepatnya $85,0 \%$.

Selanjutnya adalah fase pengenalan konsep (Concept Introduction), pada fase ini mulai mengenalkan konsep inti pelajaran 
yang harus dikaitkan langsung dengan fase eksplorasi awal. Pada fase ini di siswa bersama guru melakukan kegiatan diskusi dengan perwakilan salah satu kelompok mempresentasikan hasil diskusi dengan kelompoknya di depan kelas sehingga dalam kegiatan diskusi siswa dapat memperoleh istilah-istilah baru dan memperoleh kebenaran jawaban mereka. Setelah siswa menentukan pengetahuan baru dari kegiatan tersebut, maka siswa dapat mengungkapkan pendapatnya dengan kata-katanya sendiri untuk menanggapi jawaban teman-temannya pada fase awal.

Pada kegiatan diskusi kelas maupun diskusi kelompok siswa cenderung aktif, hal ini disebabkan karena dalam kelompok siswa merasakan adanya rasa saling ketergantungan dan saling melengkapi antara satu dengan yang lainnya untuk memperoleh hasil yang terbaik bagi semua anggota kelompok. Keaktifan siswa juga disebabkan karena selama proses pembelajaran siswa lebih interaktif sehingga siswa lebih aktif selama kegiatan diskusi. Berdasarkan hasil observasi, tampak bahwa keaktifan siswa pada saat berdiskusi mengalami peningkatan pada setiap pertemuan. Keaktifan siswa pada setiap pertemuan digambarkan pada Tabel 4.1 (dapat dilihat pada lampiran 2).

Keaktifan tersebut adalah keaktifan untuk bertanya, menjawab maupun menanggapi pertanyaan baik dari guru maupun dari teman sejawatnya. Penilaian keaktifan siswa dalam proses pembelajaran dengan menggunakan modul bahan kimia di rumah tangga ini dilihat pada setiap pertemuan pembelajaran dimana pada pertemuan pertama kegiatan siswa dalam diawali dengan kegiatan diskusi kelompok yang terbagi atas 10 kelompok dengan jumlah anggota empat orang. Dari Tabel 4.1 diperoleh pada pertemuan pertama kegiatan menjawab pertanyaan yang paling diminati oleh siswa yaitu sebanyak 7 orang, sedangkan jumlah siswa yang aktif dalam bertanya yaitu sebanyak 6 orang, menanggapi sebanyak 4 orang. Pada diskusi pertemuan 1 siswa yang aktif masih cenderung sedikit, hal ini dapat disebabkan kegiatan diskusi yang dilakukan siswa sudah sering dilakukan siswa dirumah atau kurang menarik yaitu membandingkan daya pembersih deterjen dengan merk yang berbeda-beda sehingga siswa kurang antusias karena merasa sudah pernah dilakukan di rumah.

Pada pertemuan kedua berbeda dengan pertemuan pertama. Pada pertemuan kedua ini diawali dengan mengajukan pertanyaan yang untuk memotivasi siswa tentang masalah perbedaan zat penyusun sabun dan deterjen. Selanjutnya siswa diminta untuk melakukan kegiatan eksplorasi pada bagian $\mathrm{C}$ " perbedaan sabun dan deterjen". Keaktifan siswa dalam kegiatan praktikum ini meningkat bila dibandingkan pada pembelajaran di pertemuan pertama. Hal ini terlihat pada Gambar 4.2 (dapat dilihat pada lampiran 1) yang menunjukkan jumlah siswa yang aktif mengalami kenaikan dari $51,3 \%$ menjadi $57,5 \%$ (23 orang). Selain itu, Tabel 4.1 menunjukan jumlah siswa yang aktif mengalami peningkatan dalam kegiatan menjawab sebanyak 14 orang, kegiatan bertanya yaitu 10 orang, dan kegiatan menanggapi sebanyak 7 orang kurang aktif mengalami penurunan bila dibandingkan dengan pertemuan pertama. Hal ini disebabkan karena selama proses pembelajaran siswa lebih interaktif untuk lebih tahu kegunaan dari masing-masing pembersih dan dampak dari penggunaan pembersih yang berlebihan pada lingkungan sehingga siswa lebih aktif untuk membaca materi bahan kimia di rumah tangga yang digunakan sebagai pembersih.

Untuk pertemuan ketiga kegiatan praktikum yang dilakukan pada pertemuan ketiga terbukti dapat meningkatkan keaktifan siswa dalam pembelajaran. Hal ini terlihat dari jumlah siswa yang aktif meningkat dari pertemuan sebelumnya. Selain itu, dari Gambar 4.1 (dapat dilihat pada lampiran 1) jumlah siswa yang aktif dalam menjawab sebanyak 18 orang, bertanya yaitu 14 orang, dan kegiatan menanggapi sebanyak 10 orang. 
Peningkatan jumlah siswa yang aktif disebabkan karena pada pertemuan ketiga ini, siswa diajak untuk melakukan praktikum yang berbeda dengan kegiatan praktikum pada pertemuan kedua, pada pertemuan ini praktikum yang dilakukan siswa sangat menarik yaitu "pengaruh adanya pemutih dalam air' yang dalam percobaannya menggunakan obyek ikan kecil yang masih hidup. Selain itu pada pertemuan ketiga ini siswa lebih antusias dan ingin lebih tahu dampak dari penggunaan pemutih untuk kosmetik yang sering digunakan oleh remaja putri.

Pada pertemuan keempat keaktifan siswa yang tampak pada pertemuan ini tidak jauh berbeda dengan keaktifan pada kegiatan pembelajaran pada pertemuan kedua. Besarnya jumlah siswa yang aktif dalam kegiatan menjawab sebanyak 15 orang, kegiatan bertanya sebanyak 9 orang dan kegiatan menanggapi sebanyak 9 orang. Jumlah siswa yang aktif pada pertemuan keempat mengalami penurunan. Hal ini dikarenakan kegiatan pembelajaran yang dilakukan siswa hanya sebatas membedakan kekuatan daya tahan pewangi pakaian berdasarkan keencerannnya. Hanya sebagian siswa yang terlihat sangat aktif dalam mengikuti proses pembelajaran.

Untuk pertemuan kelima keaktifan siswa mencapai jumlah tertinggi selama proses pembelajaran dengan menggunakan modul bahan kimia di rumah tangga. Pada pertemuan kelima siswa diminta untuk membawa sampel serangga yang mudah didapat di lingkungan sekitar. Siswa diminta mengkaji artikel tentang DBD dan diminta untuk mengamati perbedaan ketahanan serangga terhadap pengguanaan langsung antara obat nyamuk bakar dengan obat nyamuk semprot. Kegiatan ini dilakukan di dalam kelas. Pada pada proses pembelajaran ini jumlah siswa yang aktif menjawab pertanyaan adalah 19 orang, siswa yang aktif dalam bertanya sebesar 15 orang, dan siswa yang aktif dalam kegiatan menanggapi sebanyak 11 orang.

Pencapaian keaktifan siswa yang sangat besar pada pertemuan kelima ini dapat disebabkan karena masalah yang dilakukan pada pembelajaran kelima merupakan masalah yang dekat dengan lingkungan mereka dan bahkan mereka alami sendiri. Dilihat dari jumlah keaktifan siswa, maka diantara ketiga jenis keaktifan yang paling diminati siswa adalah keaktifan menjawab pertanyaan, sedangkan pada jenis keaktifan bertanya dan menanggapi pertanyaan siswa cenderung kurang respon. Hal ini kemungkinan disebabkan kurang terbiasanya siswa untuk aktif bertanya dan menanggapi pertanyaan serta adanya perbedaan keberanian antara siswa yang satu dengan yang lainnya. Pada fase pengenalan konsep (Concept Introduction) dengan kegiatan diskusi ini siswa dapat membangun konsep dari materi atas usahanya sendiri, sehingga mereka akan lebih mamahami apa yang sedang mereka pelajari.

Dilanjutkan lagi dengan fase pemaparan konsep (concept Application)

Pada fase ini guru meberikan situasi dimana siswa dapat menerapkan (application) penegtahuan yang telah mereka dapatkan. Siswa menerapkan konsep yang baru saja dipelajari ke dalam contoh-contoh kerja yang berkaitan dengan hal-hal praktis dalam kehidupan sehari-hari. Dalam hal ini ditentukan dalam bentuk soal-soal yang ada pada bagian aplikasi konsep dalam modul yang kemudian jawabannya harus mereka jelaskan. Pada fase ini siswa cukup antusias, hal ini disebabkan karena konsep tentang materi yang telah mereka pelajari selama proses pembelajaran dapat diaplikasikan dalam kehidupan sehari-hari. Selanjutnya fase ini guru mengarahkan siswa untuk mengambil kesimpulan tentang apa yang mereka pelajari.

Untuk fase evaluasi tidak dilakukan pada setiap akhir pembelajaran mengingat terbatasnya waktu. Tetapi fase ini dapat pula dilakukan guru pada akhir pembelajaran dengan memberikan soal-soal latihan untuk mengetahui pemahaman siswa selama pembelajaran. Bila kita lihat dari paparan proses pembelajaran learning cycle (LC) dengan menggunakan modul bahan kimia di 
rumah tangga siswa aktif dapat menemukan dan membangun konsep-konsep dalam materi yang sedang mereka pelajari atas usahanya sendiri dengan bimbingan guru.

Pada proses pembelajaran siswa juga sangat antusias dan termotivasi dalam mengikuti kegiatan pembelajaran kimia model learning cycle (LC) dengan menggunakan modul bahan kimia di rumah tangga. Guru dapat lebih banyak memberikan pertanyan-pertanyaan yang dapat menarik siswa untuk belajar agar menjawabnya. Siswa mengetahui bahwa siswa selama proses pembelajaran juga dilakukan penilaian terhadap aspek afektif dan psikomotorik, hal tersebut juga memotivasi siswa mengikuti pembelajaran kimia dengan serius.

\subsection{Ketuntasan Belajar Siswa}

Penelitian ini bertujuan untuk mengetahui ketuntasan belajar siswa dalam pembelajaran dengan menggunakan modul bahan kimia di rumah tangga. Selama proses pembelajaran menggunakan modul digunakan metode diskusi dan pada saat pembelajaran dilakukan penilaian berupa keaktifan siswa. Keaktifan siswa dalam pembelajaran merupakan bentuk hasil belajar yang diukur pada saat proses pembelajaran berlangsung. Dengan meningkatnya keaktifan siswa maka secara tidak langsung memudahkan siswa untuk menguasai materi. Selama proses pembelajaran dengan menggunakan modul siswa cenderung aktif, baik aktif untuk bertanya, menjawab maupun menganggapi pertanyaan Hal ini menunjukkan bahwa selama proses pembelajaran learning cycle (LC) dengan menggunakan modul dapat meningkatkan efisiensi dan efektifitas pembelajaran di sekolah. Apabila efisiensi dan efektifitas pembelajaran di sekolah meningkat maka mutu pelaksanaan proses pembelajaran cukup tinggi. Peningkatan mutu belajar siswa tersebut tidak lepas dari peran serta siswa karena selama proses pembelajaran siswa itu sendiri ikut aktif dan kreatif untuk berpartisipasi dalam proses pembelajaran tanpa menunggu bimbingan dari guru hal ini juga menunjukkan peningkatan kualitas belajar yang semakin baik yang dapat dilihat dari pengukuran hasil belajar pada akhir pembelajaran, sebanyak $90,0 \%$ siswa mampu mencapai ketuntasan belajar dengan skor rata-rata kelas sebesar 76,10. Hal ini menunjukkan bahwa tingginya tingkat penguasaan siswa terhadap materi bahan kimia di rumah tangga. Sebanyak 10,0\% siswa belajarnya tidak tuntas. Sebagian dari mereka merupakan siswa kelompok bawah.

Dengan adanya tingkat keaktifan dan tingkat ketuntasan belajar yang cukup tinggi, maka pembelajaran dengan menggunakan modul adalah efektif untuk diimplementasikan di sekolah.

\subsection{Persepsi siswa}

Instrumen angket digunakan untuk memperoleh data mengenai persepsi siswa terhadap modul bahan kimia di rumah tangga. Dari Gambar 4.3 (dapat dilihat pada lampiran 1) secara umum persepsi siswa tentang pembelajaran kimia dengan menggunakan modul bahan kimia di rumah tangga terlihat bahwa 22 orang siswa $(55,0 \%)$ menyatakan sangat setuju terhadap penggunaan modul bahan kimia di rumah tangga dan sisanya sebanyak 18 orang $(45,0 \%)$ menyatakan setuju terhadap penggunaan modul bahan kimia di rumah tangga dalam pembelajaran kimia. Dari hasil tersebut dapat diketahui bahwa siswa memberikan sikap yang positif terhadap pembelajaran dengan menggunakan modul model daur belajar (learning cycle) pokok bahasan bahan kimia di rumah tangga. Terbukti dari seluruh siswa yang mengalami pembelajaran dengan menggunakan modul bahan kimia di rumah tangga tidak ada yang menunjukkan sikap negatif atau sikap sangat negatif.

Untuk persepsi siswa terhadap modul bahan kimia di rumah tangga adalah 30,8\% menyatakan sangat setuju, $61,9 \%$ menyatakan setuju, 7,3\% menyatakan tidak setuju, dan $0,2 \%$ menyatakan tidak setuju. Sedangkan persepsi siswa tentang sistem pembelajaran dengan mengunkan modul 
$26,5 \%$ siswa menyatakan sangat setuju, $57,7 \%$ siswa menyatakan setuju, $15,6 \%$ siswa menyatakan tidak setuju, dan $0,2 \%$ siswa menyatakan tidak setuju. Hal ini menunjukkan bahwa sebagian besar siswa berpersepsi bahwa siswa setuju dengan adanya pembelajaran kimia dengan menggunakan modul.

Komentar yang diberikan siswa terhadap modul bahan kimia di rumah tangga sangat bervariasi. Siswa memberikan komentar bahwa modul dapat mempermudah belajar $(30,0 \%)$, menambah informasi tentang manfaat bahan kimia di rumah tangga (22,5\%), menambah informasi tentang dampak bahan kimia di rumah tangga $(27,5 \%)$, gambar yang disajikan dalam modul kurang jelas $(20,0 \%)$. Data tentang komentar siswa terhadap modul bahan kimia di rumah tangga disajikan dalam Tabel 4.3 (dapat dilihat pada lampiran 2). Untuk system pembelajaran dengan menggunakan modul siswa memberikan komentar bahwa system pembelajaran dengan menggunakan modul dapat mempermudah dalam belajar $(45,0 \%)$, dapat memotifasi belajar (17,5\%), menambah kesempatan belajar $(22,5 \%)$, kemandirian dalam belajar $(15,0 \%)$.

Dalam pembelajaran dengan modul bahan kimia di rumah tangga, terdapat beberapa cara siswa dalam mempelajari modul. Cara-cara tersebut diantaranya adalah siswa belajar dengan membaca dan memahami materi dalam modul sebesar $(22,5 \%)$, mengerjakan soal-soal dalam modul sebesar $(15,0 \%)$, belajar dengan mengukuti petunjuk dalam modul sebesar (5,0\%), mempraktekkan sendiri kegiatan yang ada pada LKS dalam modul sebesar(22,5\%), bertanya pada guru sebesar (7,5\%), mengulang pelajaran di rumah sebesar(15,0\%), mengadakan diskusi antar teman sebesar $(12,5 \%)$. Dalam pelaksanaan pembelajaran dengan menggunakan modul bahan kimia di rumah tangga terdapat beberapa hambatan yang dialami siswa selama belajar dengan menggunakan modul. Siswa menyatakan hambatan-hambatan tersebut diantaranya adalah kalimat dalam modul sulit dimengerti sebesar (12,5\%), gambar yang disajikan tidak jelas sebesar $(22,5 \%)$, dalam kegiatan percobaan sebesar $(25,0 \%)$, perbedaan informasi antara modul dengan kehidupan sehari-hari sebesar(7,5\%), dalam mengerjakan soal dan menghitung sebesar $(12,5 \%)$.

Dari hasil tersebut dapat disimpulkan bahwa siswa berpersepsi bahwa pembelajaran kimia pada pokok bahasan bahan kimia di rumah tangga dengan menggunakan modul cukup baik dan dapat meningkatkan motivasi belajar siswa.. Terbukti dari seluruh siswa yang mengalami pembelajaran dengan menggunakan modul bahan kimia di rumah tangga sebagian besar menyatakan sangat sejutu dan setuju yang merupakan persepsi yang positif dan hanya sebagian kecil siswa menyatakan tidak setuju dan sangat tidak setuju yang merupakan persepsi negatif atau persepsi sangat negatif dimana sebagian besar persepsi ini merupakan persepsi dari siswa kelompok bawah.

Persepsi yang positif dari siswa juga ditunjukkan pada keaktifan siswa baik pada saat diskusi maupun dalam kegiatan praktikum pada setiap pertemuan pembelajaran dengan menggunakan modul sesuai hasil analisis lembar observasi yang telah dibahas sebelumnya. Kesimpulan tentang persepsi siswa yang setuju terhadap penggunaan modul bahan kimia di rumah tangga memberikan pengaruh yang positif terhadap hasil belajar, peningkatan keaktifan siswa dalam belajar, motivasi belajar dan persepsi yang positif terhadap pembelajaran dengan menggunakan modul sehingga ketuntasan belajar siswa tercapai.

Peneliti memahami selama proses pembelajaran dengan menggunakan modul learning cycle (LC) dijumpai adanya kekuatan dan kelemahan yang terdapat dalam penggunaan modul bahan kimia di rumah tangga. Dari hasil observasi di lapangan selama proses pembelajaran dengan menggunakan modul terdapat kekuatan dari learning cycle (LC) antara lain: (1) siswa lebih mudah memahami konsep-konsep yang ada dalam modul 
bahan kimia di rumah tangga karena siswa dapat menemukan dan membangun konsep secara mandiri melalui usahanya sendiri dengan bimbingan dari guru; (2) menuntut siswa untuk lebih aktif berfikir. Hal ini disebabkan karena siswa diajak untuk berfikir maksimal untuk memperoleh pengetahuan baru; (3) siswa lebih berani untuk mengunkapkan pendapatnya dengan kata-katanya sendiri; (4) membuat siswa lebih tertarik pada pelajaran kimia, karena penyajian materi dalam modul cukup lengkap dan topik-topik yang diberikan sesuai dengan tingkat berfikir siswa SMP dan kehidupan sehari-hari.

Berdasarkan observasi, peneliti juga menemukan beberapa kelemahan pada modul bahan kimia di rumah tangga. Kelemahan-kelemahan tersebut diharapkan untuk direvisi atau diperbaiki guna kesempurnaan modul itu sendiri. Kelemahan-kelemahan tersebut adalah: (1) kalimat yang digunakan kurang jelas, sehingga sulit dipahami oleh siswa; (2) informasi yang ada dalam modul hendaknya disesuaikan dengan literature/ sumber yang dapat dipercaya.

Berdasarkan hal-hal di atas, maka peneliti menyimpulkan bahwa pada hakekatnya modul bahan kimia di rumah tangga yang dikembangkan oleh Susilawati (2004) adalah efektif untuk diimplentasikan dalam pembelajaran pada pokok bahasan bahan kimia di rumah tangga di SMP. Keefektifan penggunaan modul (Susilawati, 2004) untuk mengajarkan materi bahan kimia di rumah tangga dapat dilihat dari beberapa faktor, yaitu: (1) meningkatkan mutu pelaksanaan proses pembelajaran cukup tinggi yang tidak lepas dari peran serta siswa yang ikut aktif dan kreatif untuk berpartisipsi dalam proses pembelajaran tanpa menunggu bimbingan dari guru; (2) hasil belajar mencapai taraf ketuntasan belajar yang telah ditetapkan yaitu sebesar $90,0 \%$ dengan skor rata-rata kelas sebesar 76,10 yang berarti siswa sudah mampu menyerap hampir keseluruhan materi yang diajarkan; (3) persepsi siswa terhadap penggunaan pembelajaran dengan menggunakan modul model (learning cycle) menunjukan hasil yang positif. Hal ini ditunjukkan dengan $55,0 \%$ (22 orang) menunjukkan sikap sangat setuju dan 18 orang siswa $(45,0 \%)$ menunjukkan sikap setuju.

\section{KESIMPULAN DAN SARAN 4.1 Kesimpulan}

Dari kesimpulan umum keefektifan implementasi modul bahan kimia di rumah tangga tersebut dapat dijabarkan menuju kesimpulan yang lebih operasional yakni: 1) Selama proses pembelajaran dengan menggunakan modul bahan kimia di rumah tangga aktivitas siswa cenderung tidak tetap. Dalam setiap skenario pembelajaran, keaktifan siswa pada proses pembelajaran pada setiap pertemuan mengikuti tahaptahap dalam modul terkadang mengalami kenaikan tetapi pada skenario pembelajaran selanjutnya terkadang mengalami penurunan. Namun secara umum keaktifan siswa pada setiap pertemuannya cukup tinggi baik pada keaktifan pada saat praktikum maupun pada kegiatan diskusi yang meliputi tiga jenis keaktifan, yaitu keaktifan menjawab, bertanya, dan menanggapi pertanyaan. Hal ini terlihat dari jumlah siswa yang cenderung aktif dalam setiap pertemuan pembelajaran cukup tinggi. Dari data hasil persentase aktivitas siswa tersebut menunjukkan bahwa pembelajaran dengan menggunakan modul model learning cycle (LC) memberikan pengaruh yang positif terhadap keaktifan siswa dalam proses pembelajaran sehingga mutu pelaksanaan proses pembelajaran cukup tinggi yang tidak lepas dari peran serta siswa yang ikut aktif dan kreatif untuk berpartisipsi dalam proses pembelajaran tanpa menunggu bimbingan dari guru. 2) Berdasarkan hasil analisis data skor tes siswa untuk materi bahan kima di rumah tangga diperoleh ketuntasan belajar sebesar 90,0\% dengan skor rata-rata kelas sebesar 76,10 . Hal ini menunjukkan bahwa hasil belajar telah memenuhi kriteria standar ketuntasan belajar mengajar (SKBM). 3) Berdasarkan hasil analisis data skor hasil 
pengolahan angket persepsi siswa terhadap penggunaan pembelajaran dengan menggunakan modul learning cycle (LC) diperoleh $55,0 \%$ (22 orang) menyatakan sangat setuju dan 18 orang siswa $(45,0 \%)$ menyatakan setuju. Hal ini menunjukkan bahwa siswa menyetujui pelaksanaan pembelajaran dengan menggunakan modul bahan kimia di rumah tangga model learning cycle (LC).

\subsection{Saran}

Adapun saran-saran yang dapat peneliti sampaikan berdasarkan hasil penelitian yang telah diperoleh adalah: untuk perbaikan modul yang terlalu tebal sehingga perlu diringkas terutama uraian yang tidak pokok disingkat agar penggunaan modul dapat efektif dan efisien. Adapun saran-saran dalam penggunaan bahan ajar yang diharapkan adalah: 1) Pembelajaran dengan menggunakan modul model (learning cycle) dapat digunakan untuk mengembangkan siswa dalam hal keaktifan dan kemandirian, sikap tanggung jawab dalam belajar dan mengemukakan pendapat dan berfikir kritis. Oleh karena itu, bila pembelajaran dengan menggunakan modul model (learning cycle) digunakan secara tepat maka pembelajaran dengan menggunakan modul dapat berfungsi sebagai suplemen/ komplemen dari pengajaran dengan metode ceramah atau jenis aktivitas belajar mengajar lain di kelas. 2) Dari hasil penelitian yang menunjukkan bahwa prestasi belajar siswa dengan skor rata-rata kelas sebesar 76,10 memenuhi SKBM (standar ketuntasan belajar mengajar) secara nasional, dengan ketuntasan kelas sebesar 90,0\%. Maka disarankan guru menerapkan model (learning cycle) dengan berbantuan modul yang dapat disesuaikan dengan materi yang akan dibahas. 3) Perlu adanya penelitian lanjutan dengan menggunakan populasi yang lebih luas untuk mengetahui apakah terdapat hasil yang sama jika pembelajaran dengan modul dilakukan di sekolah lain.

\section{DAFTAR PUSTAKA}

Afiati, Z. 2002. Strategi Pembelajaran

Fisika Berbasis Aktivitas Untuk

Meningkatkan Motivasi Belajar Siswa

Kelas I MTs Negeri Malang III.

Skripsi tidak diterbitkan. Malang:

Universitas Negeri Malang.

Ali, M. 1984. Guru Dalam Proses belajar Mengajar. Bandung: Sinar baru.

Arikunto, S. 2002. Dasar-dasar Evaluasi Pendidikan. Jakarta: Bumi Aksara.

Arikunto, S. 2002. Prosedur Penelitian Suatu Pendekatan Praktek. Edisi Revisi V. Jakarta: Bumi Aksara.

Asfar, Z. 2003. Ketuntasan Belajar Fisika Melalui Keterampilan Proses Pokok Bahasn Optik Geometric Pada Siswa Kelas II MA Mambaul Ulum Corogo Jogoroto jombang Semester Genap Tahun Pelajaran 2002/2003. Skripsi Tidak Diterbikan. Malang: Universitas Negeri Malang.

Dasna, I. W. 2005. Model siklus Belajar (Learning Cycle) Kajian teoritis dan Implementasinya Dalam Pembelajaran Kimia. Dalam I Wayan Dasna dan Sutrisno (Eds.), ModelModel Pembelajaran Konstruktivistik Dalam Pengajaran Sains/ Kimia (halaman 66-85). Malang: FMIPAUM

Depdiknas. 2003. Standar Kompetensi Mata Pelajaran Sains SMP da MTS Kurikulum 2004. Jakarta: Depdiknas.

Fakhrudin, P.S. 1989. Hubungan Antara Persepsi Jabatan Guru dengan Proses Belajar Mengajar Mahasiswa Program Diploma Kependidikan IKIP Malang. Skripsi Tidak Diterbikan. Malang: Universitas Negeri Malang.

Hardiono, B. 2000. Kontribusi Efisiensi Dan Efektivitas Penggunaan 
Perpustakaan Serta Efektifitas Proses Belajar Mengajar Terhadap Prestasi Belajar Siswa SMU Negeri Se- Kota Malang. Tesis Tidak Diterbitkan. Malang: Universitas Negeri Malang.

Hidayat. 1986. Seminar Nasional Pembelajaran Pendidikan. Bandung: IKIP Bandung.

Ischak, S.W. \& Warji, R. 1987. Program Remedial Dalam Proses Belajar Mengajar. Yogyakarta: Liberti.

Johson, S. 2004. Sains Kimia SMP Kelas VII. Jakarta: Erlangga

Lembaga Penelitian. 2003. Pedoman Penulisan Karya Ilmiah. Malang: Lembaga Penelitian IKIP Malang.

Lembaga Penelitian. 2003. Metodologi Penelitian. Malang: Lembaga Penelitian IKIP Malang.

Lisnawati. 2006. Persepsi Guru IPA dan Siswa SMP Negeri Darul Ulum Pereongan Jombang Tentang Prospek Pengajaran Kimia Di SMP. Skripsi Tidak Diterbitkan. Malang: Universitas Negeri Malang.

Mulyasa. 2002. Kurikulum Berbasis Kompetensi Konsep, karakteristik, dan Implementasinya. Bandung: PT. Remaja Rosdakarya.

Marsandi, W. 1978. Belajar Tuntas (Mastery Learning). Jakarta: Departemen Pendidikan dan Kebudayaan. $\mathrm{BP}_{3} \mathrm{~K}$.

Nurhadi. 2004. Kontekstual Dan Penerapannya Dalam KBK. Malang: UM.

Newcomb, Turner, dan Converse. Tanpa Tahun. Psikologi Sosial. Terjemahan oleh Josoef Noesfirman. 1985. Bandung: CV Diponegoro.
Mar'at. 1982. Sikap Manusia Perubahan Serta Pengukurannya. Bandung: Ghalia Indonesia.

Pannen, P. 2001. Konstruktivisme Dalam Pembelajaran. Jakarta: Pusat Antar Universitas Untuk Peningkatan Dan Pengembangan Aktivitas Instruksional Direktorat Jenderal Pendidikan Tinggi. Departemen Pendidikan Nasional.

Wahyuni, R. T. 2002. Pengaruh Penggunaan Modul Dengan Prinsip Belajar Tuntas Terhadap Proses Pembelajaran Fisika, Respon Siswa Dan Prestasi Belajar Fisika Siswa Kelas I-5 SMU Laboratorium UM Tahun Pelajaran 2002/2003. Skripsi Tidak Diterbitkan. Malang: Universitas Negeri Malang.

Rahayu, S. 2001. Kecendrungan Pembelajaran Kimia di Awal Abad 21. Makalah Disampaikan Dalam Seminar Nasional di UNY.

Subandi, dkk. 2005. Sains Kimia Untuk SMP. Malang: Universitas Negeri Malang.

Suparno, P. 1997. Filsafat Konstruktivisme Dalam Pendidikan. Yogyakarta: Audi Kanisius

Susilawati, R. 2004. Pengembangan Modul Bahan Kimia Di Rumah Tangga Menurut Model Daur Belajar (Learning Cycle) Untuk Pembelajaran Sains Kimia SMP Kelas VII Sesuai dengan Kurikulum SMP 2004. Skripsi Tidak Diterbitkan. Malang: Universitas Negeri Malang.

Wasih, D. S. 1999. Daur Belajar (LC) Sebagai Pendekatan Alternatif Dalam Pembelajaran IPA Wahana Sekolah Dasar. Tahun 7 No 2. 
Zahera. 2000. Cara Guru Memotivasi dan Pengaruhnya Terhadap Aktivitas Siswa Dalam Proses Belajar Mengajar. Jurnal Ilmu Pendidikan, 1(1): 25-34.

(_ ). 2005. Dangerous Chemicals in the Home A "Most-Wanted" list of five common household contaminants.

(http://www.Dangerous.ardc.org/healt h/home/fchems.asp. Diakses Jum'at 21 juli 2006 05.30)

(— ). 2001. Kurikulum Mapel Kimia (bag.1). (Online)

(http://www.Puskor.or.id/data/2004/st andar\%20kompetensi/standar\%20kom petensi\%20.SMP.MTS/06\%20pengeta huan\%20Alam pdf \# search= 'kurikulum\%20sains\%20 SMP. Diakses Minggu 16 oktober 2005 05.30)

\section{Kosmetik}

(http://www.suara.merdeka.com/cyber news/wanita/ksp/tips6.html. Diakses Sabtu 22 juli 2006 05.30)

(— ). 2003. Soap and Saponification, Preparation and Chemical Structure (http://www.molecules.forces.atwork:creati ng.soap.bubbles. Diakses Sabtu 22 juli 2006 07.00) 
Lampiran 1 Kumpulan Gambar Diagram

Gambar 4.1 Diagram Perkembangan Keaktifan Siswa Dalam Setiap Pertemuan.

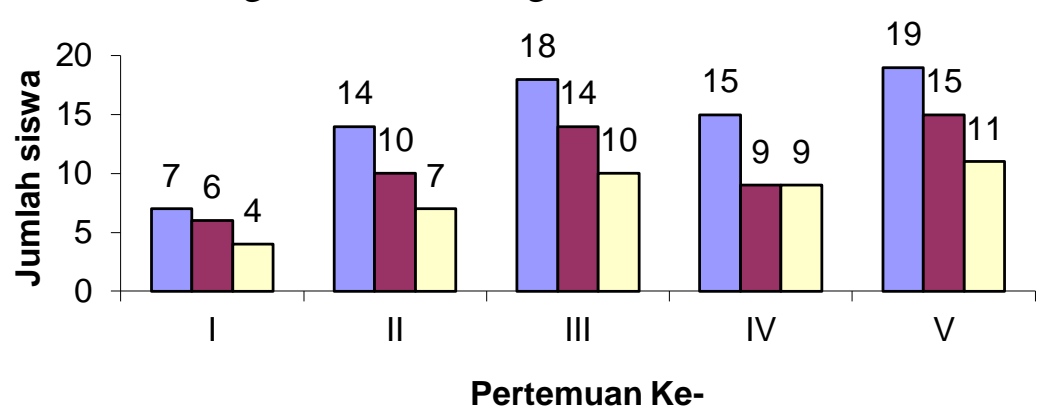

口Menjawab घBertanya $\square$ Menanggapi

Gambar 4.2 Diagram Perkembangan Persentase Keaktifan Siswa Dalam Setiap Kegiatan Pembelajaran. (Pada setiap pertemuan siswa tidak menunjukkan kriteria kurang aktif dan tidak aktif)

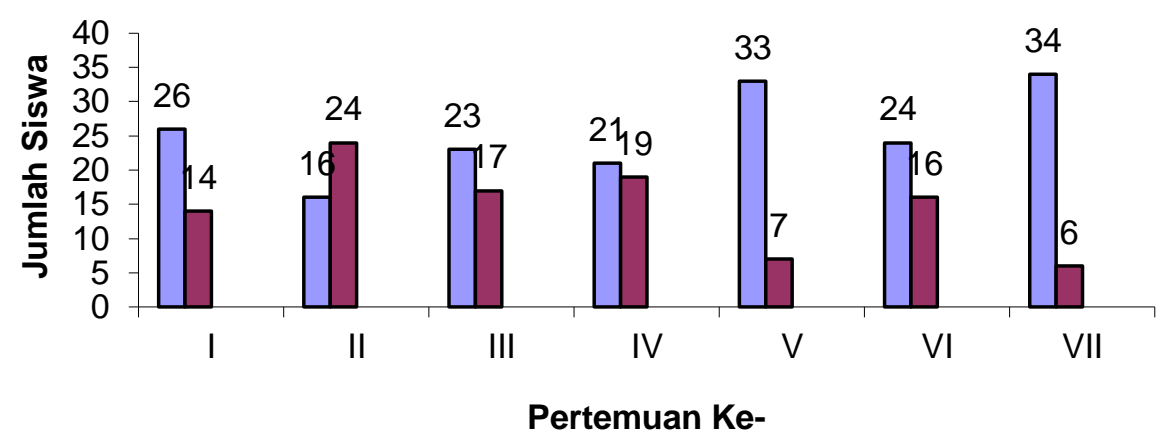

口Sangat aktif $\quad$ Aktif

Gambar 4.3 Diagram Persepsi Siswa terhadap Pembelajaran dengan Menggunakan Modul Learning Cycle (LC). (tidak ada siswa yang menyatakan tidak setuju atau sangat tidak setuju)

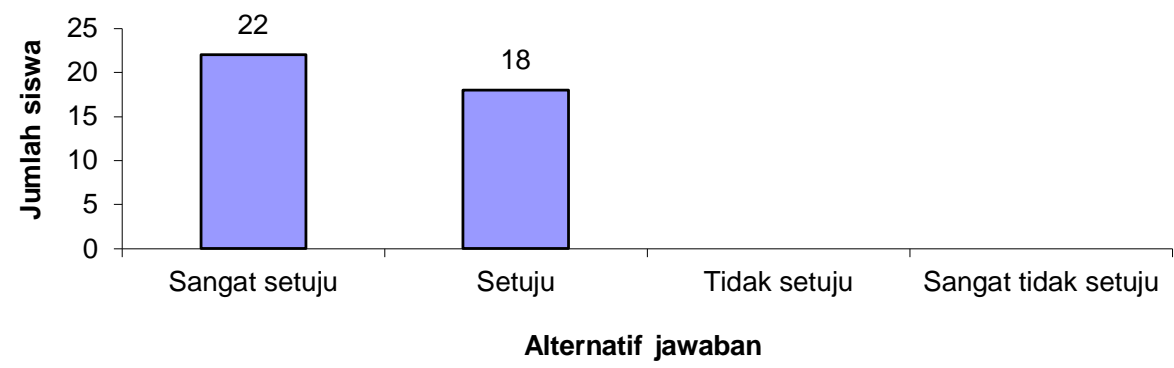


Lampiran 2 Kumpulan Tabel

Tabel 4.1 Perkembangan Keaktifan Siswa Pada Saat Diskusi Dalam Setiap Pertemuan

\begin{tabular}{cccccc}
\hline \multirow{2}{*}{ Kriteria } & \multicolumn{5}{c}{ Pertemuak ke- } \\
\cline { 2 - 6 } & I & II & III & IV & V \\
\hline Menjawab & 7 & 14 & 18 & 15 & 19 \\
\hline Bertanya & 6 & 10 & 14 & 9 & 15 \\
\hline Menanggapi & 4 & 7 & 10 & 9 & 11 \\
\hline$\sum$ siswa & 17 & 31 & 42 & 33 & 45 \\
\hline
\end{tabular}

Tabel 4.2 Perkembangan Keaktifan Siswa Pada Saat Praktikum Dalam Setiap Kegiatan Pembelajaran

\begin{tabular}{lcccccccccccccc}
\hline Kriteria & \multicolumn{1}{c}{ Jumlah Siswa } & \multicolumn{1}{c}{ Persentase } \\
\cline { 2 - 14 } & I & II & III & IV & V & VI & VII & I & II & III & IV & V & VI & VII \\
\cline { 2 - 7 } & 26 & 16 & 23 & 21 & 33 & 24 & 34 & 65 & 40 & 58 & 53 & 83 & 60 & 85 \\
aktif & 14 & 24 & 17 & 19 & 7 & 16 & 6 & 35 & 60 & 43 & 48 & 18 & 40 & 15 \\
\hline Aktif & - & - & - & - & - & - & - & - & - & - & - & - & - & - \\
\hline $\begin{array}{l}\text { Kurang } \\
\text { aktif }\end{array}$ & & & & & & & & & & & & & & \\
\hline Tidak aktif & - & - & - & - & - & - & - & - & - & - & - & - & - & - \\
\hline
\end{tabular}

Tabel 4.3 Distribusi Frekuensi Komentar Siswa Terhadap Modul Bahan Kimia di Rumah Tangga

\begin{tabular}{clcc}
\hline No & \multicolumn{1}{c}{ Komentar } & Frekuensi & Persentase \\
\hline 1. & Dapat mempermudah belajar & 12 & 30,0 \\
2. & $\begin{array}{l}\text { Menambah informasi tentang manfaat bahan kimia } \\
\text { di rumah tangga }\end{array}$ & 9 & 22,5 \\
3. & $\begin{array}{l}\text { Menambah informasi tentang dampak bahan kimia } \\
\text { di rumah tangga }\end{array}$ & 11 & 27,5 \\
4. & Gambar kurang jelas & 8 & 20,0 \\
\hline & Jumlah & 40 & 100,0 \\
\hline
\end{tabular}

